\title{
Hubungan Motivasi Dengan Prestasi Belajar Siswa
}

\author{
Ni Wyn. Dian Pratiwi ${ }^{1}$, I.G.A. Agung Sri Asri², M.G. Rini Kristiantari ${ }^{3}$ \\ 1,2,3 Jurusan Pendidikan Guru Sekolah Dasar, FIP Universitas Pendidikan Ganesha, Singaraja
}

\author{
A RTICLEIN \\ $\mathrm{FO}$ \\ Article history: \\ Received 10 May \\ 2018 \\ Received in revised \\ form \\ 17 June 2018 \\ Accepted 19 July \\ 2018 \\ Available online 28 \\ August 2018 \\ Kata Kunci: \\ Motivasi, Prestasi \\ Belajar \\ Keywords: \\ Motivation, Learning \\ Achievement.
}

\begin{abstract}
A B STRAK
Penelitian ini bertujuan untuk mengetahui hubungan motivasi dengan prestasi belajar siswa kelas V SD Negeri Gugus 1 Kuta Selatan Tahun Ajaran 2016/2017. Jenis penelitian ini adalah ex post facto (korelasional). Populasi dari penelitian ini adalah seluruh siswa kelas V SD Negeri Gugus 1 Kuta Selatan Tahun Ajaran 2016/2017, yang berjumlah 421 siswa. Sampel penelitian berjumlah 191 siswa. Teknik penentuan sampel yang digunakan adalah teknik proporsional random sampling. Data yang dikumpulkan adalah data kuantitatif dengan skala interval yaitu motivasi dan prestasi belajar siswa, metode pengumpulan data menggunakan metode non tes. Data tentang motivasi didapat melalui angket motivasi, sedangkan data tentang prestasi belajar didapat melalui pencatatan dokumen. Analisis statistik yang digunakan dalam penelitian ini adalah analisis korelasi product moment. Hasil yang didapat menunjukkan terdapat hubungan yang signifikan antara motivasi dengan prestasi belajar diperoleh rhitung $=0,151$ dan rtabel 0,138 pada taraf signifikansi $(\square=0,05, n=191)$ maka demikian rhitung $=0,151>$ rtabel $=0,138$, ini berarti nilai rhitung signifikan. Maka disimpulkan bahwa terdapat hubungan yang signifikan antara motivasi dengan prestasi belajar siswa kelas V SD Negeri Gugus 1 Kuta Selatan Tahun Ajaran 2016/2017.
\end{abstract}

\section{A B S TR A C T}

This study aims to determine the relationship of motivation with the achievement of students in grade V SD Negeri Gugus 1 South Kuta Academic Year 2016/2017. This type of research is ex post facto (correlational). The population of this study is all students of grade V SD Negeri Gugus 1 South Kuta Academic Year 2016/2017, which amounted to 421 students. The sample of the study amounted to 191 students. Sample determination technique used is proportional random sampling technique. The data collected are quantitative data with interval scale that is motivation and student achievement, data collection method using non test method. Data on motivation is obtained through questionnaire of motivation, while data about learning achievement obtained through document recording. Statistical analysis used in this research is product moment correlation analysis. The result shows that there is a significant correlation between motivation and learning achievement obtained rhitung $=0,151$ and rtabel 0,138 at significance level $(\square=0,05, n=191)$ hence rhitung $=0,151>$ rtabel $=0,138$, this means significant value rhitung. Then it is concluded that there is a significant relationship between the motivation with the achievement of students in grade V SD Negeri Gugus 1 Kuta Selatan Academic Year 2016/2017.

\footnotetext{
* Corresponding author.

E-mail addresses: dianpratiwi227@yahoo.com (Ni Wyn. Dian Pratiwi)
} 



\section{Pendahuluan}

Pendidikan pada jenjang sekolah dasar berfungsi sebagai peletak dasar-dasar keilmuan dan membantu meng-optimalkan perkembangan anak. Menurut Irham dan Novan (2013:19), pendidikan merupakan usaha mendewasakan dan memandirikan manusia melalui kegiatan yang terencana dan disadari melalui kegiatan belajar dan pembelajaran yang melibatkan siswa dan guru. Selanjutnya, dalam Undang-Undang No. 20 Tahun 2003 tentang Sistem Pendidikan Indonesia tertulis,

Pendidikan adalah usaha sadar dan terencana untuk mewujudkan suasana belajar dan proses pembelajaran agar peserta didik secara aktif mengembangkan potensi dirinya untuk memiliki kekuatan spiritual keagamaan, pengendalian diri, kepribadian, kecerdasan, akhlak mulia, serta keterampilan yang diperlukan dirinya, masyarakat, bangsa dan negara.

Jadi, pendidikan adalah usaha sadar dan terencana dalam mendewasa-kan dan memandirikan manusia melalui kegiatan belajar dan pembelajaran yang melibatkan siswa dan guru agar peserta didik secara aktif mengembangkan potensi dirinya untuk memiliki kekuatan spiritual keagamaan,pengendalian diri kepribadian,kecerdasan,akhlak mulia serta keterampil-an yang diperlukan dirinya, masyarakat, bangsa dan negara. Pendidikan merupakan cerminan kegiatan belajar yang melibatkan siswa dan guru. Menurut Syah (2003:63), belajar adalah kegiatan yang sangat fundamental dalam penyelenggaraan setiap jenis jenjang pendidikan. Selanjutnya Sardiman (2008:21) memaparkan, belajar berarti usaha mengubah tingkah laku. Lebih lanjut, Sagala (2013:11) memaparkan, belajar merupakan ilmu pendidikan yang berkenaan dengan tujuan dan bahan acuan interaksi. Jadi, belajar adalah komponen ilmu pendidikan yang fundamental dalam penyelenggaran setiap jenis dan jenjang pendidikan sebagai usaha mengubah tingkah laku.

Kegiatan belajar di sekolah dasar memiliki beberapa muatan materi pembelajaran untuk dibelajarkan pada siswa, diantaranya IPA, IPS, Matematika, Bahasa Indonesia dan PKn. Kegiatan belajar perlu didukung dengan adanya motivasi. Menurut Santrock (2011:510), motivasi adalah proses memberi semangat arah dan kegigihan perilaku. Selanjutnya Uno (2012:1), memaparkan motivasi adalah dorongan untuk menggerakkan seseorang bertingkah laku. Jadi, motivasi adalah proses memberi semangat dan arah sebagai dorongan untuk menggerakkan seseorang bertingkah laku.

Perubahan tingkah laku dalam kegiatan belajar berhubungan dengan motivasi. Faktor terpenting yang dapat meningkatkan hasil belajar siswa adalah motivasi belajar siswa itu sendiri (Pranomo, 2014). Peranan motivasi dalam kegiatan belajar berfungsi untuk menumbuhkan gairah dan semangat untuk belajar sehingga dapat menumbuhkan minat siswa terhadap pelajaran yang dipelajari. Apabila ada motivasi yang kuat maka se-seorang akan bersungguh sungguh dalammencurahkan segala perhatiannya untuk mencapai tujuan belajarnya (Wahyuni, 2010:3). Tujuan belajar dapat didukung dengan keberadaan motivasi belajar pada siswa.

Menurut Santrock (2011:510), motivasi adalah proses yang memberi semangat, arah dan kegigihan perilaku. Artinya, perilaku yang termotivasi adalah perilaku yang penuh energi, terarah dan bertahan lama. Motif akan berubah men-jadi motivasi jika mendapatkan stimulasi. Jika sumber stimulasi berasal dari dalam individu, motivasinya disebut motivasi intrinsik. Sementara motivasi ekstrinsik terjadi jika individu melakukan sesuatu karena alasan-alasan eksternal seperti ingin menyenangkan orang lain (guru, orang tua) atau untuk menghindari hukuman.

Motivasi dalam kegiatan belajar, dapat dikatakan sebagai keseluruhan daya penggerak di dalam diri siswa yang menimbulkan kegiatan belajar, yang menjamin kelangsungan dari kegiatan belajar dan memberikan arah pada kegiatan belajar. Hal ini sejalan dengan pendapat Gunadi (2014) yang menyatakan motivasi memengaruhi apa, kapan, dan bagaimana siswa belajar. Menurut Uno (2012:23), motivasi belajar adalah dorongan internal dan eksternal pada siswa-siswa yang sedang belajar untuk mengadakan perubahan tingkah laku. Selanjutnya Sardiman (2008:75),memaparkan motivasi belajar merupakan faktor psikis yang berrsifat non intelektual. Jadi, motivasi belajar adalah factor psikis berupa dorongan internal dan eksternal pada siswa yang sedang belajar untuk mengadakan pe-rubahan tingkah laku. Motivasi belajar dapat dilakukan melalui dua bentuk, yakni motivasi ekstrinsik dan motivasi intrinsik. Motivasi ekstrinsik adalah dorongan yang timbul untuk mencapai tujuan yang datang dari luar dirinya. Sedangkan motivasi intrinstik adalah dorongan yang timbul dari dalam diri siswa (Nurdin, 2015).

Keberadaan motivasi belajar dapat mendorong usaha untuk pencapaian prestasi belajar siswa. Prestasi belajar dianggap sebagai suatu cerminan keberhasilan kegiatan belajar. Menurut Susanto (2013:5), prestasi belajar adalah kemampuan yang diperoleh siswa setelah melalui kegiatan belajar. Prestasi belajar mencakup segala hal yang dipelajari di sekolah, baik itu menyangkut pengetahu-an, sikap, dan keterampilan yang berkait-an dengan mata pelajaran yang diberikan kepada siswa. Prestasi belajar merupakan hasil yang dicapai siswa dalam usaha belajarnya yang terlihat terlihat dari nilai yang 
diperoleh. Antari (2015) dalam penelitiannya mengatakan bahwa lingkungan merupakan salah satu faktor yang mempengauhi prestasi belajar siswa.

Penelitian yang dilakukan oleh Louisa Nicolina Kandoli (2011:Vol.2) menunjukkan adanya hubungan antara motivasi dan prestasi belajar siswa. Berdasarkan uraian teori motivasi dan prestasi serta didukung oleh penelitian Louisa Nicolina Kandoli (2011:Vol.2), maka dirancang pelaksanaan kegiatan penelitian expost facto dengan judul: Hubungan Motivasi Siswa dengan Prestasi Belajar Siswa Kelas V SD Negeri Gugus I Kuta Selatan Tahun Ajaran 2016/2017.

Tujuan dari penelitian ini adalah untuk mengetahui ada tidaknya hubungan yang signifikan antara motivasi dengan prestasi belajar siswa kelas V SD Negeri Gugus 1 Kuta Selatan Tahun Ajaran 2016/2017.

\section{Metode}

Penelitian ini adalah penelitian korelasional yang bersifat ex post facto. Penelitian korelasional bertujuan untuk melihat hubungan variabel satu sama lain; sedangkan ex post facto adalah metode penelitian dimana variabel bebas yang diteliti tidak dapat dikendalikan secara langsung.

Jadi penelitian dilakukan tanpa eksperimen, artinya variabel bebas atau perlakuan (treatment) telah terjadi secara apa adanya (alamiah) tanpa dimanipulasi, dan pengukuran (pengumpulan data) untuk semua variabel dilakukan dalam waktu yang sama, setelah perlakuan berjalan lanjut.

Teknik yang digunakan dalam meng-ambil sampel adalah teknik proporsional

random sampling. Dalam penentuan sampel dapat dilihat pada tabel Issac and Michael dan pendekatan rumus tersebut didapat jumlah sampel dari populasi, yang kemudian dicari tiap-tiap sampel dari sebaran populasi yang ada di kelas V Gugus 1 Kuta Selatan.

Sesuai dengan tabel tersebut, pada jenjang pendidikan digunakan tingkat kesalahan 5\%, jumlah populasi kelas V SD Negeri Gugus 1 Kuta Selatan Tahun Ajaran 2016/2017 sebanyak 421 siswa, pada tabel Issac and Michel dengan jumlah populasi di kelas V SD Negeri Gugus 1 Kuta Selatan Tahun Pelajaran 2016/2017 sebanyak 421 siswa, jadi jumlah sampel yang diambil dengan tingkat kesalahan 5\% adalah 191 siswa.

Metode pengumpulan data dilakukan untuk memperoleh informasi yang dibutuhkan dalam rangka mencapai tujuan penelitian. Dalam penelitian terdapat dua cara untuk mengumpulkan data, yaitu dengan metode tes dan metode non tes. Menurut Suharsimi (2010) metode penelitian adalah cara yang digunakan oleh penliti dalam mengumpulkan data penelitiannya. Ada dua cara pengumpulan dta yaitu melalui tes dan non tes.

Suharsimi (2010:195), memapar-kan "Angket atau kuisioner adalah sejumlah pertanyaan tertulis yang digunakan untuk memperoleh informasi dari responden dalam arti laporan tentang pribadinya, atau hal-hal yang ia ketahui".

Metode pengumpulan data yang paling utama digunakan dalam penelitian ini yaitu melalui angket. Angket dalam penelitian ini bersifat tertutup agar terdapat kesamaan jawaban masing-masing responden sehingga proses pengolahan datanya lebih mudah. Angket dengan model skala likert ini akan memudahkan responden dalam menjawab pertanyaan atau pernyataan yang telah disediakan dalam angket tersebut. Untuk memberi skor skala likert, jawaban diberi bobot dengan nilai kuantitatif 5,4,3,2,1 untuk empat pilihan pernyataan positif. Sedangkan untuk pilihan pernyataan negatif diberi bobot atau nilai kuantitatif $1,2,3,4,5$.

Penelitian ini meneliti dua variabel, yaitu variabel independen (variabel bebas) dan variabel dependen (variabel terikat). Variabel independen atau variabel bebas mempengaruhi variabel dependen atau variabel. Variabel bebas dalam penelitian ini adalah motivasi siswa (X), dan yang menjadi variabel terikat adalah prestasi belajar (Y). Prestasi belajar diperoleh dari nilai rapot semester satu.

Data penelitian yang sudah terkumpul selanjutnya akan dilakukan analisis data. Dalam penelitian ini, analisis data yang digunakan adalah analisis statistik deskriptif, analisis deskriptif kuantitatif, dan analisis statistik inferensial. Metode analisis data dilakukan untuk menguji apakah data yang telah didapatkan memenuhi persyaratan untuk analisis dengan teknik analisis yang ditetapkan.

Variabel bebas merupakanvariabel yang menyebabkan atau memengaruhi faktor yang diukur, atau faktor yang digunakan untuk menentukan hubungan antara fenomena yang di amati (Setyosari, 2013). Variabel bebas dalam penelitian ini adalah motivasi siswa.

Variabel terikat umumnya yang menjadi pusat permasalahan, sehingga sering disebut sebagai variabel kriterium. "Variabel terikat adalah variabel yang dipengaruhi atau yang menjadi akibat, karena adanya variabel bebas" (Sugiyono, 2016:39). Jadi dapat disimpulkan variabel terikat adalah variabel yang dipengaruhi oleh variabel bebas. Variabel terikat dalam penelitian ini yaitu prestasi belajar. Prestasi belajar adalah hasil belajar yang dicapai oleh siswa setelah siswa yang bersangkutan mengalami suatu 
proses belajar di sekolah dalam jangka waktu tertentu. Data dari prestasi belajar dilakukan dengan metode pencatatan dokumen hasil belajar siswa yang telah ada di sekolah.

Berdasarkan bentuk-bentuk motivasi siswa yang diungkapkan oleh Santrock (2010) maka disusunlah angket motivasi siswa terdiri dari 40 pernyataan, diantaranya 25 pertanyaan positif dan 15 pertanyaan negative. Cara pemberian skornya adalah untuk pertanyaan yang positif pilihan sangat setuju skornya 5, setuju skornya 4, cukup setuju skornya 3, kurang setuju skonya 2, tidak setuju 1 . Sedangkan, untuk statemen yang negatif pilihan sangat setuju skornya 1, setuju skornya 2, cukup setuju skornya 3 , kurang setuju skonya 4, tidak setuju 5 (Sugiyono, 2016:93).

Instrumen angket dalam penelitian ini terdiri dari 40 butir soal yang diuji cobakan kepada 35 siswa, kemudian hasil tes uji coba tersebut dianalisis validitasnya. Berdasarkan hasil analisis diperoleh 35 butir soal yang valid dan 5 butir soal yang tidak valid yang dapat dilihat pada tabel berikut.

Tabel 1. Rekapitulasi Hasil Analisis Uji Validitas Butir Angket

\section{Nomor Butir Soal yang Valid}

\section{Nomor Butir Soal yang Tidak Valid}

$1,2,3,4,6,7,8,11,12,13,14,15,16,17,18,19,20,22, \quad 9,21,32,38,40$
$24,25,26,27,29,30,31,33,34,35,36,37,39$

Reliabilitas merupakan alat untuk mengukur sejauh mana alat ukur yang digunakan dapat dipercaya. Uji reliabilitas soal dilakukan untuk mengetahui ukuran yang menyatakan tingkat keajegan atau kekonsistenan suatu soal tes. Dalam penelitian ex post facto uji reliabilitas juga diberlakukan pada soal dalam angket. Untuk mengukur tingkat keajegan soal ini digunakan perhitungan Alpha Cronbach karena tes bersifat politomi.

Kriteria uji reliabilitas dengan rumus alpha adalah apabila harga $r_{\text {hitung }}>r_{\text {tabel, }}$, maka alat ukur tersebut reliabel dan juga sebaliknya, jika harga $r_{\text {hitung }}<r_{\text {tabel }}$ maka alat ukur tidak reliabel. Jika instrumen itu valid, maka dilihat kriteria penafsiran mengenai indeks $r_{11}$ sebagai berikut :

a) Antara 0,800 sampai dengan 1,000 : sangat tinggi.

b) Antara 0,600 sampai dengan 0,799: tinggi.

c) Antara 0,400 sampai dengan 0,599: cukup.

d) Antara 0,200 sampai dengan 0,399: kurang.

e) Antara 0,000 sampai dengan 0,100: sangat rendah.

Tabel 2. Rekapitulasi Hasil Analisis Uji Reliabilitas Butir Angket

\begin{tabular}{ccc}
\hline Kriteria & Koefisien Reliabilitas & Keterangan \\
\hline Harga $\mathrm{r}_{\mathrm{hitung}}>\mathrm{r}_{\text {tabel }}$ & $0,859>0,330$ & Reliable \\
\end{tabular}

Berdasarkan hasil analisis uji reliabilitas yang dilakukan diperoleh koefisien reliabilitasnya sebesar 0,859. Hal ini menunjukkan bahwa soal tes tersebut reliable.

Data penelitian yang sudah ter-kumpul selanjutnya akan dilakukan analisis data. Dalam penelitian ini, analisis data yang digunakan adalah analisis statistik deskriptif, analisis deskriptif kuantitatif, dan analisis statistik inferensial. Metode analisis data dilakukan untuk menguji apakah data yang telah didapatkan memenuhi persyaratan untuk analisis dengan teknik analisis yang ditetapkan.

Menurut Sugiyono (2016), mengungkapkan bahwa statistik deskriptif adalah statistik yang digunakan untuk menganalisis data dengan cara men-deskripsikan data yang telah terkumpul tanpa bermaksud membuat kesimpulan yang berlaku untuk umum atau generalisasi.

Metode analisis statistik deskriptif adalah suatu cara pengolahan data yang dilakukan dengan menerapkan rumus-rumus statistik deskriptif, seperti distribusi frekuensi, grafik, median, modus, mean, dan standar deviasi untuk menggambar-kan suatu objek/variable tertentu, sehingga diperoleh kesimpulan umum (Agung, 2014). 
Statistik Deskriptif yang digunakan untuk mendeskripsikan data dalam penelitian ini yaitu mean dan standar deviasi. Metode analisis deskriptif kuantitatif digunakan untuk mengetahui kriteria dari prestasi belajar siswa yang dikonversikan ke dalam klasifikasi pada skala lima teoritik. Rumus yang digunakan untuk menganalisis dalam menentukan rata-rata persentase prestasi belajar belajar siswa adalah sebagai berikut.

Tabel 3. Skala penilaian atau kategori/ klasifikasi pada skala lima teoretik

\begin{tabular}{|c|c|}
\hline Rentang & Kategori \\
\hline $\mathrm{M}_{\mathrm{i}}+1,5 \mathrm{SDi}-<\mathrm{Mi}+3,0 \mathrm{SD}_{\mathrm{i}}$ & Sangat Baik \\
\hline $\mathrm{M}_{\mathrm{i}}+0,5 \mathrm{SDi}-<\mathrm{Mi}+1,5 \mathrm{SD}_{\mathrm{i}}$ & Baik \\
\hline $\mathrm{M}_{\mathrm{i}}-0,5 \mathrm{SDi}-<\mathrm{Mi}+0,5 \mathrm{SD}_{\mathrm{i}}$ & Kurang Baik \\
\hline $\mathrm{M}_{\mathrm{i}}-1,5 \mathrm{SDi}-<\mathrm{Mi}-0,5 \mathrm{SD}_{\mathrm{i}}$ & Tidak Baik \\
\hline $\mathrm{M}_{\mathrm{i}}-3,0 \mathrm{SDi}-<\mathrm{Mi}-1,5 \mathrm{SD}_{\mathrm{i}}$ & Sangat Tidak Baik \\
\hline
\end{tabular}

Uji prasyarat dilakukan terlebih dahulu sebelum uji hipotesis. Uji prasyarat tersebut meliputi uji normalitas data variabel bebas dan data variabel terikat. Uji normalitas bertujuan untuk mengetahui apakah data masing-masing sampel dari populasi normal atau tidak. Uji normalitas data dilakukan dengan menggunakan analisis Chi-Kuadrat.

Berdasarkan hasil analisis uji normalitas data di bawah ini disajikan ringkasan hasil uji normalistas motivasi dan prestasi belajar dengan menggunakan rumus Chi-Kuadrat.

Tabel 4. Hasil Uji Normalitas Motivasi dan Prestasi belajar

\begin{tabular}{llll}
\hline \multicolumn{1}{c}{ Variabel } & \multicolumn{1}{c}{$\mathbf{X}^{2}$ hitung } & \multicolumn{1}{c}{$\mathbf{X}^{2}$ tabel } & Keterangan \\
\hline Motivasi & 6,270 & 11,07 & Normal \\
\hline Prestasi belajar & 6,811 & 11,07 & Normal \\
\hline
\end{tabular}

Dari hasil analisis uji normalitas motivasi Harga tersebut kemudian dibandingkan dengan harga $\mathrm{X}^{2}$ tabel dengan $\mathrm{db}=5$ dan taraf signifikansi 5\% sehingga diperoleh $\mathrm{X}^{2}$ tabel $=11,07$. Karena $\mathrm{X}^{2}{ }_{\text {hitung }}=6,27<$ $\mathrm{X}_{\text {tabel }}=11,07$, maka $\mathrm{H}_{\mathrm{o}}$ diterima atau $\mathrm{H}_{\mathrm{a}}$ ditolak. Ini berarti sebaran data angket motivasi berdistribusi normal.

Sedangkan hasil analisis uji normalitas data prestasi belajar tersebut kemudian dibandingkan dengan harga $\mathrm{X}^{2}$ tabel dengan $\mathrm{db}=5$ dan taraf signifikansi $5 \%$ sehingga diperoleh $\mathrm{X}^{2}$ tabel $=11,07$, karena $\mathrm{X}^{2}$ hitung $=6,81<\mathrm{X}_{\text {tabel }}=11,07$, maka $\mathrm{H}_{\mathrm{o}}$ diterima atau $\mathrm{H}_{\mathrm{a}}$ ditolak. Ini berarti sebaran data prestasi belajar berdistribusi normal.

Data yang diperoleh telah memenuhi asumsi prasyarat analisis, maka analisis yang digunakan adalah statistik parametris. Analisis statistik yang digunakan untuk menguji hipotesis penelitian ini adalah analisis product moment.

Untuk menguji analisis product moment dilakukan dengan langkah-langkah sebagai berikut:

1) Menuliskan $\mathrm{H}_{a}$ dan $\mathrm{H}_{0}$ dalam bentuk kalimat

$\mathrm{H}_{\mathrm{a}}$ = Terdapat hubungan yang signifikan antara motivasi siswa dengan prestasi belajar siswa kelas $\mathrm{V}$ SD Negeri di Gugus 1 Kuta Selatan Tahun Ajaran 2016/2017.

$\mathrm{H}_{0}=$ Tidak terdapat hubungan yang signifikan antara motivasi siswa dengan prestasi belajar siswa kelas V SD Negeri di Gugus 1 Kuta Selatan Tahun Ajaran 2016/2017.

2) Menuliskan $\mathrm{H}_{a}$ dan $\mathrm{H}_{0}$ dalam bentuk statistik

$\mathrm{Ha}=\mathrm{r} \neq 0$

$\mathrm{HO}=\mathrm{r}=0$

3) Membuat tabel penolong

4) Menghitung a dengan rumus

$$
\mathrm{a}=\frac{\left(\Sigma \mathrm{Y}_{i}\right)\left(\Sigma \mathrm{X}_{i}^{2}\right)-\left(\Sigma \mathrm{X}_{i}\right)\left(\Sigma \mathrm{X}_{i} \mathrm{Y}_{i}\right)}{\mathrm{n} \Sigma \mathrm{X}_{i}^{2}-\left(\Sigma \mathrm{X}_{i}\right)^{2}}
$$

5) Menghitung b dengan rumus 


$$
\mathrm{b}=\frac{\mathrm{n} \Sigma \mathrm{X}_{i}^{2} \mathrm{Y}_{\mathrm{i}}-\left(\Sigma \mathrm{X}_{i}\right)\left(\Sigma \mathrm{Y}_{i}\right)}{\mathrm{n} \Sigma \mathrm{X}_{i}^{2}-\left(\Sigma \mathrm{X}_{i}\right)^{2}}
$$

6) Membuat kesimpulan

\section{Hasil dan Pembahasan}

Penelitian ini memaparkan tentang data motivasi siswa sebagai variabel bebas $(\mathrm{X})$ dan data prestasi belajar sebagai variabel terikat (Y) yang ditampilkan dalam tabel dan grafik.

Data tentang motivasi siswa kelas $\mathrm{V}$ di Gugus 1 Kuta Selatan diperoleh melalui penyebaran angket. Sampel yang di-bagikan angket sebanyak 191 responden, dan diberikan dengan 35 pernyataan angket, diperoleh skor terbesar adalah 167 dan skor terkecil adalah 132 berikut.

Dari data di atas dapat juga dilihat dalam bentuk histogram, sehingga dapat dilihat sebagai

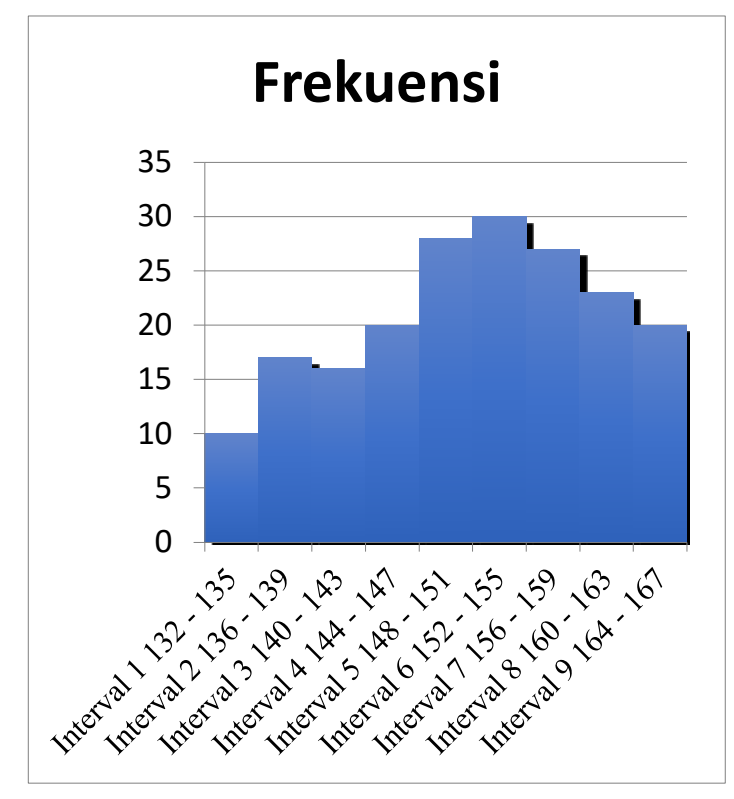

Gambar 1. Skor Motivasi Siswa

Skor motivasi siswa kemudian dikategorikan sesuai dengan skala penilaian atau kategori/klasifikasi pada skala lima teoretik.

Tabel 5. Skala Penilaian atau Kategori Skor Motivasi

\begin{tabular}{lll}
\hline Rentang & Hasil & Kategori \\
\hline$M_{i}+1,5 \mathrm{SDi}-<\mathrm{Mi}+3,0 \mathrm{SD}_{\mathrm{i}}$ & $139.95-174.90$ & Sangat baik \\
\hline $\mathrm{M}_{\mathrm{i}}+0,5 \mathrm{SDi}-<\mathrm{Mi}+1,5 \mathrm{SD}_{\mathrm{i}}$ & $116.65-139.95$ & Baik \\
\hline $\mathrm{M}_{\mathrm{i}}-0,5 \mathrm{SDi}-<\mathrm{Mi}+0,5 \mathrm{SD}_{\mathrm{i}}$ & $93.35-116.65$ & Kurang baik \\
\hline $\mathrm{M}_{\mathrm{i}}-1,5 \mathrm{SDi}-<\mathrm{Mi}-0,5 \mathrm{SD}_{\mathrm{i}}$ & $70.05-93.35$ & Tidak baik \\
\hline $\mathrm{M}_{\mathrm{i}}-3,0 \mathrm{SDi}-<\mathrm{Mi}-1,5 \mathrm{SD}_{\mathrm{i}}$ & $35.1-70.05$ & Sangat tidak baik \\
\hline & & (Sumber : Koyan, 2012:25)
\end{tabular}

Dari tabel kategori skor motivasi siswa diatas serta hasil dari analisis data, bahwa rerata (mean) dari kemampuan motivasi siswa adalah 146,9 dan nilai tersebut berada pada kategori skor 139,95 174,90. Maka dapat disimpulkan bahwa kemampuan motivasi siswa kelas V di Gugus 1 Kuta Selatan tergolong sangat baik. 
Data prestasi belajar yang di-gunakan adalah nilai rapot semester satu siswa kelas V di Gugus 1 Kuta Selatan dari 191 siswa. Dari data nilai rapot diperoleh nilai tertinggi adalah 94 dan nilai terendah adalah 63. berikut.

Dari data di atas dapat juga dilihat dalam bentuk histogram, sehingga dapat dilihat sebagai

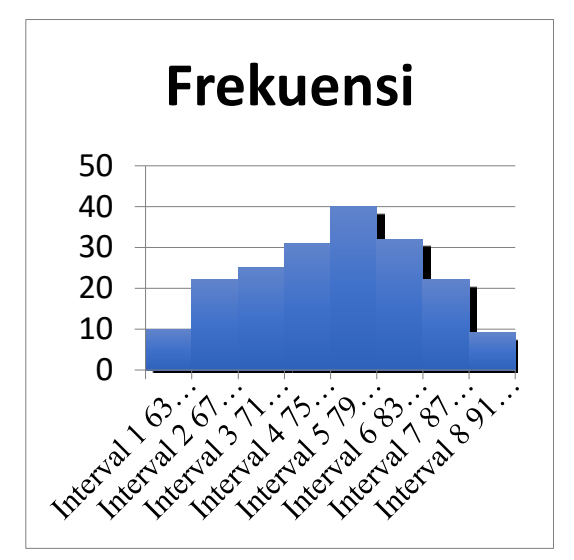

Gambar 2. Data Prestasi Siswa.

Tabel 6. Deskripsi Data Prestasi belajar

\begin{tabular}{lll}
\hline \multicolumn{1}{c}{ Statistik } & Prestasi belajar \\
\hline Nilai Terbesar & 94 & \\
\hline Nilai Terkecil & 63 \\
\hline Median & 79,25 \\
\hline Varians & 57,47 & \\
\hline Standar Deviasi & 7,58 & \\
\hline
\end{tabular}

Nilai prestasi belajar siswa kemudian dikategorikan sesuai dengan norma kerangka teoritik kurva normal ideal.

Tabel 7. Skala Penilaian atau Kategori Nilai Prestasi belajar

\begin{tabular}{lll}
\hline \multicolumn{1}{c}{ Rentang } & \multicolumn{1}{c}{ Hasil } & \multicolumn{1}{c}{ Kategori } \\
\hline $\mathrm{M}_{\mathrm{i}}+1,5 \mathrm{SDi}-<\mathrm{Mi}+3,0 \mathrm{SD}_{\mathrm{i}}$ & $77,50-100,00$ & Sangat baik \\
\hline $\mathrm{M}_{\mathrm{i}}+0,5 \mathrm{SDi}-<\mathrm{Mi}+1,5 \mathrm{SD}_{\mathrm{i}}$ & $62,50-77,50$ & Baik \\
\hline $\mathrm{M}_{\mathrm{i}}-0,5 \mathrm{SDi}-<\mathrm{Mi}+0,5 \mathrm{SD}_{\mathrm{i}}$ & $47,50-62,50$ & Kurang baik \\
\hline $\mathrm{M}_{\mathrm{i}}-1,5 \mathrm{SDi}-<\mathrm{Mi}-0,5 \mathrm{SD}_{\mathrm{i}}$ & $32,50-47,50$ & Tidak baik \\
\hline $\mathrm{M}_{\mathrm{i}}-3,0 \mathrm{SDi}-<\mathrm{Mi}-1,5 \mathrm{SD}_{\mathrm{i}}$ & $10,00-32,50$ & Sangat tidak baik \\
\hline & & (Sumber : Koyan, 2012:25)
\end{tabular}

Dari tabel kategori prestasi belajar diatas serta hasil dari analisis data, bahwa rerata (mean) dari prestasi belajar siswa adalah 78,72 dan nilai tersebut berada pada rentang 77,50 - 100,00. Maka dapat disimpulkan bahwa prestasi belajar siswa kelas V di Gugus 1 Kuta Selatan tergolong sangat baik.

Berdasarkan hasil analisis data diketahui koefisien korelasi $\left(\mathrm{r}_{\mathrm{x} \mid \mathrm{y}}\right)$ antara motivasi $(\mathrm{X})$ dengan prestasi belajar (Y) siswa kelas V SD di Gugus 1 Kuta Selatan Tahun Ajaran 2016/2107 dengan nilai $r_{\text {hitung }}$ $=0,151$ dan $r_{\text {tabel }}=0,138(n=191)$ pada taraf signifikansi 5\%. Sehingga $H_{1}$ yang menyatakan terdapat hubungan yang signifikan antara motivasi terhadap prestasi belajar siswa kelas V SD di Gugus 1 Kuta Selatan Tahun Ajaran 2016/2107. 
Hal tersebut didukung oleh Santrock (2011:510), motivasi adalah proses yang memberi semangat, arah dan kegigihan perilaku. Artinya, perilaku yang termotivasi adalah perilaku yang penuh energi, terarah dan bertahan lama. Motif akan berubah menjadi motivasi jika mendapatkan stimulasi. Jika sumber stimulasi berasal dari dalam individu, motivasinya disebut motivasi intrinsik. Sementara motivasi ekstrinsik terjadi jika individu melakukan sesuatu karena alasan-alasan eksternal seperti ingin menyenangkan orang lain (guru, orang tua) atau untuk menghindari hukuman.

Keberhasilan belajar seorang siswa tidak hanya ditentukan dari faktor sekolah saja, begitu juga keberhasilan pencapaian siswa dalam mempelajari ilmu pengetahuan. Faktor yang mempengaruhi belajar diantaranya faktor internal dan faktor eksternal. Motivasi adalah salah satu faktor yang berpengaruh terhadap prestasi belajar. Dengan kata lain, motivasi merupakan salah satu faktor penting yang dapat mempengaruhi prestasi belajar. Memotivasi anak dalam kegiatan belajar akan sangat berpengaruh bagi anak untuk dapat lebih giat belajar sehingga dapat meraih prestasi belajar yang baik. Begitu pula sebaliknya, bila kurang atau rendahnya motivasi dalam kegiatan belajar anakmaka akan berpengaruh pada prestasi belajarnya pula.

$\mathrm{H}_{0}=$ Tidak terdapat hubungan yang signifikan antara motivasi dengan prestasi belajar siswa kelas V SD

di Gugus 1 Kuta Selatan Tahun Ajaran 2016/2017.

Pengujian hipotesis penelitian yang akan menggunakan analisis korelasi sederhana untuk mengetahui hubungan antara motivasi dengan prestasi belajar. Tabel penolong uji hipotesis dapat dilihat pada lampiran 27.

Melihat dua variabel tersebut berhubungan atau tidak, maka terdapat kriteria diantaranya sebagai berikut:

1) Jika $r$ hitung $>$ dari $r$ tabel maka Ho ditolak

2) Jika $r$ hitung $<$ dari $r$ tabel maka Ho diterima

3) Jika $r$ hitung $>r$ tabel maka Ho ditolak sehingga terdapat hubungan antara motivasi dengan prestasi belajar

$r_{x y}=\frac{\sum x y}{\sqrt{\sum x^{2} y^{2}}}=\frac{2088,75}{\sqrt{(17471,1)(10918,7)}}=0.151$

Keterangan :

$r_{x y}=$ korelasi antara variabel $\mathrm{x}$ dengan $\mathrm{y}$

$\mathrm{x}=\left(\mathrm{x}_{\mathrm{i}}-\overline{\mathcal{X}}\right.$

$\mathrm{y}=\left(\mathrm{y}_{\mathrm{i}}-\bar{y}\right.$

Pada taraf signifikansi $(\alpha=0,05, \mathrm{n}=191)$ maka demikian $r_{\text {hitung }}=0,151>r_{\text {tabel }}=0,138$, ini berarti

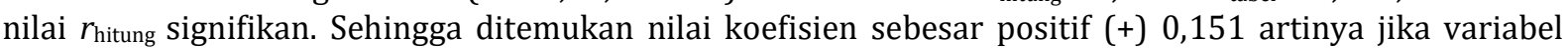
motivasi naik maka variabel prestasi belajar juga akan naik.

\section{Simpulan dan Saran}

Berdasarkan hasil penelitian yang diperoleh dapat disimpulkan bahwa terdapat hubungan antara motivasi siswa dengan prestasi belajar siswa. Arah korelasi adalah positif karena nilai r positif, berarti semakin tinggi motivasi maka semakin meningkatkan prestasi belajar siswa. Dengan demikian, dapat disimpul-kan bahwa motivasi berhubungan dengan prestasi belajar siswa kelas V SD Negeri Gugus 1 Kuta Selatan Tahun Ajaran 2016/2017.

Berdasarkan simpulan yang di-peroleh, adapun saran yang dapat di-sampaikan yaitu kepada: Para guru dapat menjadikan hasil Penelitian ini sebagai masukan dan sebagai bahan pertimbangan untuk mengetahui hubungan antara motivasi dan prestasi belajar siswa. Penelitian ini di-lakukan pada sampel yang terbatas. Para peneliti lain yang tertarik disarankan untuk melakukan penelitian terhadap motivasi siswa dan prestasi belajar siswa dengan sampel yang lebih luas dan subjek yang berbeda untuk mengetahui hubungan motivasi siswa terhadap prestasi belajar siswa secara lebih mendalam. Dari penelitian ini, diharapkan siswa dapat lebih memotivasi diri untuk meningkatkan prestasi belajarnya. Selain itu siswa, diharapkan dapat selalu meningkatkan rasa ingin tahu melalui bertanya apabila ada yang belum di pahami, agar pengembangan pola pikir siswa dapat lebih luas, kritis dan inovatif. Diharapkan dengan hasil penelitian ini sekolah mampu mengadakan kebijakan baru terkait dengan meningkatkan kualitas proses pembelajaran di sekolah demi kualitas mutu pendidikan yang lebih baik. 


\section{Daftar Rujukan}

Agung, A.A. Gede. 2014. Metodologi Penelitian Pendidikan. Singaraja: Universitas Pendidikan Ganesha.

Agung, A.A. Gede. 2016. Stastistik Dasar Untuk Pendidikan. Yogyakarta: Deepublish.

Antari, S R S. , K. Suma, N K. Rapi. 2015. Suasana Kelas Dalam Pembelajaran Fisika: Wahana Pengembangan Kecerdasan Emosional, Sikap Ilmiah Dan Prestasi Belajar Fisika. Jurnal Wahana Matematika dan Sains, Volume 9, Nomor 1.

Dantes, N. 2012. Metode Penelitian. Yogyakarta: Andi Yogyakarta.

Dantes, N. 2014. Analisis dan Desain Eksperimen. Singaraja: Program Pascasarjana Undiksha.

Dantes, N. 2017. Desain Eksperimen dan Analisis Data. Depok: Rajawali Pers.

Gunadi, Chintia Leo, William Gunawan. 2014. Hubungan Motivasi Akademik Dengan Prestasi Belajar Siswa Sma 'X' Di Jakarta Barat. Jurnal NOETIC Psychology Volume 4 Nomor 1.

Irham, Muhamad, dkk. 2013. Psikologi Pendidikan. Jogjakarta: AR-RUZZ Media.

Kandoli, Louisa Nicolina. 2011. "Motivasi Dan Hubungannya Dengan Prestasi Belajar Mahasiswa Pada Mata Kuliah Tata Hidang Di Jurusan Pkk Fakultas Teknik." Jurnal Skripsi (tidak diterbitkan). Volume 2, Nomor 2 (hlm. 103). Tersedia pada http://pps.unj.ac.id/journal/jpd/ article/view/383 (diakses tanggal 2 Februari 2017).

Kosasih, E. 2016. Strategi Belajar dan Pembelajaran Implementasi Kurikulum 2013. Bandung: Yrama Widya.

Koyan, I Wayan. 2012. Statistik Pendidikan. Teknik Analisis dan Kuantitatif. Singaraja: Universitas Pendidikan Ganesha Press.

Latipah, Eva. 2012. Pengantar Psikologi Pendidikan.Yogyakarta:Pedagogia.

Nurdin. 2015. Hubungan Motivasi Belajar Terhadap Prestasi Belajar Pendidikan Kewarganegaraan. Faktor Jurnal Ilmiah Kependidikan Vol. II No. 2

Pranomo , Wisnu Wibowo. 2014. Hubungan Motivasi Belajar Dengan Prestasi Belajar Siswa Kelas X Teknik Pemesinan Di Smk Antartika 1 Sidoarjo. JPTM, Volume 3 Nomor 1, Hal. 114 - 120

Reid, Gavin. 2009. Memotivasi Siswa di Kelas: Gagasan dan Strategi. Jakarta: PT. Indeks.

Sagala, Syaiful. 2013. Konsep dan Makna Pembelajaran. Bandung: Alfabeta.

Sanjaya, Wina. 2014. Penelitian Pendidikan. Jakarta: Kencana Prenada Media Group.

Santrock, John W. 2011. Psikologi Pendidikan. Terjemahan Tri Wibowo B.S. Educational Psichology. 2004. Jakarta: Kencana.

Sardiman. 2008. Interaksi dan Motivasi Belajar Mengajar. Jakarta: PT. Raja Grafindo Persada.

Sardiman. 2016. Interaksi \& Motivasi Belajar Mengajar. Jakarta: Rajawali Pers.

Setyosari, Punaji. 2013. Metode Penelitian Pendidikan dan Pengembangan. Jakarta: Kencana.

Setyosari, P.A. 2015. Metode Penelitian Pendidikan. Jakarta: Prenadamedia Group.

Slavin, Robert R. 2011. Psikologi Pendidikan. Jakarta: PT. Indeks. 
Sri Susandi Ulandari, Komang. 2014. "Hubungan Antara Motivasi Belajar Dengan Prestasi Belajar Siswa SD Kelas V Semester Ganjil Di Desa Buruan." Jurnal Mimbar PGSD Universitas Pendidikan Ganesha. Volume 2, Nomor 1 (hlm. 119). Tersedia pada http://pps.unj.ac.id/journal/jpd/ article/view/383 (diakses tanggal 25 Februari 2017).

Sudjana, Nana. 2005. Penilaian Hasil Proses Belajar Mengajar. Bandung: PT. Remaja Rosdakarya.

Sugiyono. 2014. Metodologi Penelitian Pendidikan. Bandung: Alfabeta.

Sugiyono. 2016. Metode Penelitian Kuantitatif, Kualitatif Dan R\&D. Bandung: Alfabeta.

Suharsimi, Arikunto. 2014. Prosedur Penelitian. Jakarta: Rineka Cipta.

Suharsimi. 2015. Dasar-dasar Evaluasi Pendidikan. Jakarta: PT. Bumi Aksara.

Sukardi. 2009. Metodologi Penelitian Pendidikan. Jakarta: PT. Bumi Aksara.

Susanto, Ahmad. 2013. Teori Belajar dan Pembelajaran di Sekolah Dasar. Jakarta: Kencana.

Syah, Muhibin. 2003. Psikologi Belajar. Jakarta: PT Rajagrafindo Persada.

Undang-Undang Republik Indonesia Nomor 20 Tahun 2003 tentang Sistem Pendidikan Nasional. 2003. Jakarta: Sekretaris Negara Republik Indonesia.

Universitas Pendidikan Ganesha. 2009. Pedoman Penulisan Skripsi Dan Tugas Akhir. Singaraja: UNDIKSHA.

Uno, Hamzah B. 2012. Teori Motivasi dan Pengukurannya. Jakarta: PT. Bumi Aksara.

Wahab, Rohmalina. 2016. Psikologi Belajar. Jakarta: Rajawali Pers.

Wahyuni, Esa Nur. 2010. Motivasi dalam Pembelajaran. Malang: UIN-Malang Press.

Wijayani, Isnaini, Een Y. Haenilah, Sugiman Sugiman. 2017. Hubungan Motivasi Belajar dengan Prestasi Belajar Siswa Kelas . Jurnal Pedagogi, Vol 6, No 6.

Yulistiana. 2014. "Hubungan Motivasi Berprestasi Dan Persepsi Pada Metode Pembelajaran Problem Solving Terhadap Hasil Belajar Biologi Siswa." Jurnal Skripsi (tidak diterbitkan). Volume 4, Nomer 2 (hlm. 160). Tersedia pada http:jurnal.fkip.unila.ac.id/index.php/JPF/article/view/12498 (diakses tanggal 25 Februari 2017). 